JRPB, Vol. 7, No. 1, Maret 2019, Hal. 126 - 138

DOI: $10.29303 /$ jrpb.v7i1.106

ISSN 2301-8119, e-ISSN 2443-1354

Tersedia online di http://jrpb.unram.ac.id/

\title{
ANALISIS EKONOMI ALAT PENGERING BIJI KAKAO TIPE BAK SISTEM PENGHEMBUS UDARA PANAS (STUDI KASUS DI DESA PENENGAHAN KECAMATAN GEDONG TATAAN KABUPATEN PESAWARAN PROVINSI LAMPUNG)
}

\author{
Economic Analysis of Batch Type Cocoa Beans Dryer Hot Air Blower System \\ (Case Study in Penengahan Village Gedong Tataan Subdistrict \\ Pesawaran District Lampung Province) \\ Thareh Kemal Damanta ${ }^{1, *}$, Sandi Asmara ${ }^{2}$, Dwi Dian Novita', Tamrin² \\ ${ }^{1}$ Jurusan Teknik Pertanian, Universitas Lampung \\ Email*): tharehkemal@yahoo.com \\ Diterima: Desember 2018 \\ Disetujui: Maret 2019
}

\begin{abstract}
Cocoa is one of the main agricultural commodities that have important role in Indonesian economy. The quality of cocoa beans is very much influenced by the condition of cocoa and its processing methods, one of which is drying. The alternative drying process for cocoa beans that can be used is batch type dryer. The advantages of this tool are that the drying time is shorter, does not require a lot of labor, the temperature and speed of the drying process can be adjusted as desired, and cleanliness can be monitored as well as possible. The purpose of this research is to find out the profit/income per year that will be obtained and to find out the economic feasibility value of the type of cocoa bean dryer like a hot air blowing system in Penengahan Village, Gedong Tataan Subdistrict, Pesawaran District, Lampung Province. The research was conducted from April - May 2018 in Penengahan Village, Gedong Tataan Subdistrict, Pesawaran District, Lampung Province. The data needed in conducting this economic analysis is obtained from quantitative data supported by qualitative data, this is done to get accurate results. Quantitative data was obtained by directly interviewing farmers with various questions (questionnaire) as a tool for collecting data. While qualitative data is obtained by making observations or direct measurements in the field. These data were filled into tables that match the data and details of the costs that have been incurred. The results showed that the annual income from this drying business was Rp 42.242.668,01/year, and is considered financially feasible as indicated by the NPV value (Rp 165.318.779,07/year) which is positive, B / C Ratio (1,07)> (1), and IRR (554,36\%)> bank interest rates (7\%). Based on the sensitivity analysis, changes in the increase in production costs, a decrease in revenues, and a decrease in working hours showed that the drying of cocoa beans was still feasible.
\end{abstract}

Keywords: batch type dryer, cocoa beans, economic analysis 


\begin{abstract}
ABSTRAK
Kakao adalah salah satu komoditas pertanian andalan dengan peranan penting dalam perekonomian Indonesia. Mutu biji kakao sangat dipengaruhi oleh kondisi kakao dan cara pengolahannya, salah satunya yaitu pengeringan. Alternatif proses pengeringan biji kakao yang dapat digunakan yaitu pengering tipe bak. Kelebihan dari alat ini yaitu waktu penjemuran lebih singkat, tidak memerlukan banyak tenaga kerja, suhu dan kecepatan proses pengeringan dapat diatur sesuai keinginan, dan kebersihan dapat diawasi sebaik-baiknya. Tujuan dari penelitian ini adalah untuk mengetahui keuntungan/ pendapatan per tahun yang akan diperoleh dan untuk mengetahui nilai kelayakan ekonomi dari alat pengering biji kakao tipe bak sistem penghembus udara panas di Desa Penengahan, Kecamatan Gedong Tataan, Kabupaten Pesawaran, Provinsi Lampung. Penelitian ini dilaksanakan pada bulan April - Mei 2018 di Desa Penengahan, Kecamatan Gedong Tataan Kabupaten Pesawaran, Provinsi Lampung. Data-data yang diperlukan dalam melakukan analisis ekonomi ini diperoleh dari data kuantitatif yang didukung oleh data kualitatif, hal ini dilakukan untuk mendapatkan hasil yang akurat. Data kuantitatif diperoleh dengan mewawancarai secara langsung petani pemilik alat menggunakan daftar pertanyaan (kuesioner) sebagai alat bantu pengumpulan data. Sedangkan data kualitatif diperoleh dengan melakukan pengamatan atau pengukuran langsung di lapangan. Data-data tersebut diisi kedalam tabel yang sesuai dengan data dan rincian biaya yang telah dikeluarkan. Hasil penelitian menunjukkan bahwa pendapatan per tahun dari usaha pengeringan ini yaitu sebesar $\mathrm{Rp}$ 42.242.668,01/tahun, dan dinilai layak secara finansial yang ditunjukkan dengan nilai NPV (Rp 165.318.779,07/tahun) bernilai positif, B/C Ratio $(1,07)>(1)$, dan IRR $(554,36 \%)>$ suku bunga bank $(7 \%)$. Berdasarkan analisis sensitivitas, perubahan terhadap kenaikan biaya produksi, penurunan penerimaan, dan penurunan jam kerja alat menunjukkan bahwa usaha pengeringan biji kakao tetap layak untuk dilakukan.
\end{abstract}

Kata kunci: analisis ekonomi, biji kakao, pengering tipe bak

\section{PENDAHULUAN}

\section{Latar Belakang}

Indonesia merupakan negara penghasil kakao terbesar ketiga di dunia setelah negara Pantai Gading dan Ghana. Luas lahan tanaman kakao Indonesia kurang lebih 992.448 Ha dengan produksi biji kakao sekitar 456.000 ton per tahun, dan produktivitas rata-rata $900 \mathrm{~kg}$ per $\mathrm{Ha}$ (Departemen Perindustrian, 2007). Salah satu daerah penghasil kakao di Indonesia adalah Provinsi Lampung. Provinsi Lampung merupakan salah satu daerah sentral penghasil kakao. Produksi kakao Provinsi Lampung mencapai 21.000 ton per tahun atau yang terbesar keenam dibandingkan provinsi lain di Indonesia. Volume ekspor kakao Provinsi Lampung menempati urutan ketujuh atau sebesar $1,15 \%$ dari total ekspor dan nilai ekspor terbesar keenam atau sebesar 4,65\% dari total ekspor (BPS Provinsi Lampung, 2015). Kakao adalah salah satu komoditas pertanian andalan dengan peranan penting dalam perekonomian Indonesia. Hal ini karena Indonesia merupakan penghasil biji kakao (cacao beans) terbesar ketiga di dunia dengan pangsa produksi sebesar 15,68\% (Sadimantara, dkk., 2014). Biji kakao dapat menghasilkan beberapa produk olahan seperti bubuk kakao serta lemak kakao. Mutu biji kakao sangat dipengaruhi oleh kondisi kakao dan cara pengolahannya. Pengolahan biji kakao terdiri atas serangkaian proses yang panjang sehingga diperoleh biji kakao yang memenuhi persyaratan perdagangan, memiliki cita rasa yang memuaskan serta tidak berbahaya bagi kesehatan konsumen (Harsanti, dkk., 2012). Pengeringan biji kakao terbagi menjadi dua yaitu pengeringan alami (sun drying) dan 
pengeringan buatan (artificial drying). Pengeringan alami adalah penjemuran langsung di bawah sinar matahari. Pengeringan alami dilakukan untuk menurunkan kadar air dan membentuk warna pada biji. Sedangkan pengeringan buatan adalah pengeringan dengan menggunakan alat pengering yang menggunakan bahan bakar. Pengeringan buatan dilakukan untuk mengurangi kadar air pada biji sampai kadar air yang telah ditetapkan. Pengeringan penting untuk dilakukan karena berguna untuk memperoleh kualitas yang lebih baik dan seragam, baik bahan mentah maupun produk akhir yang dihasilkan untuk mencapai mutu kakao yang baik (Napitupulu dan Tua, 2012).

Di Desa Penengahan Kecamatan Gedong Tataan, pengeringan biji kakao yang dipakai pengepul biji kakao adalah pengering buatan dengan tipe bak. Pengering buatan digunakan guna mengantisipasi masalah cuaca yang tidak menentu seperti di Indonesia. Sehingga dengan adanya pengering buatan dapat membantu pengepul biji kakao dalam melakukan proses pengeringan. Adapun kelebihan penggunaan mesin pengering biji kakao tipe bak yaitu waktu penjemuran lebih singkat, tidak memerlukan banyak tenaga kerja, suhu dan kecepatan proses pengeringan dapat diatur sesuai keinginan, dan kebersihan dapat diawasi sebaikbaiknya.

Dalam kegiatan pengeringan biji kakao, pengepul seringkali hanya memikirkan keuntungan dalam jangka pendek dan bisa menghasilkan laba yang lebih baik, walaupun terkadang mengeluarkan biaya yang berlebih. Pengepul biji kakao di Desa Penengahan memilih untuk melakukan pengeringan biji kakao hanya sekedar ingin memenuhi kebutuhan hidup dan ikut orang lain. Pengepul kurang memahami bagaimana kegiatan tersebut mampu bertahan dan menguntungkan sampai dalam jangka panjang. Untuk itu diperlukan analisis kelayakan terhadap pengeringan biji kakao ditinjau dari aspek finansial agar dapat memberikan gambaran kepada pengepul biji kakao bagaimana melakukan kegiatan pengeringan biji kakao yang menguntungkan dengan mempertimbangkan berbagai macam biaya dan faktor produksi yang akan dikeluarkan dalam kegiatan pengeringan biji kakao menggunakan alat pengering biji kakao tipe bak sistem penghembus udara panas.

\section{Tujuan Penelitian}

Tujuan dari penelitian ini adalah sebagai berikut:

1. Untuk mengetahui laba per tahun yang akan diperoleh dari alat pengering biji kakao tipe bak sistem penghembus udara panas di Desa Penengahan, Kecamatan Gedong Tataan, Kabupaten Pesawaran.

2. Untuk mengetahui nilai kelayakan ekonomi dari alat pengering biji kakao tipe bak sistem penghembus udara panas di Desa Penengahan, Kecamatan Gedong Tataan, Kabupaten Pesawaran.

\section{METODE PENEITIAN}

\section{Waktu dan Tempat Penelitian}

Penelitian ini dilaksanakan pada bulan April - Mei tahun 2018 di Desa Penengahan, Kecamatan Gedong Tataan, Kabupaten Pesawaran, Lampung.

\section{Alat dan Bahan Penelitian}

Alat yang digunakan pada penelitian ini adalah alat pengering biji kakao tipe bak, kipas (blower), timbangan duduk besar, kalkulator, dan laptop.

Bahan-bahan yang digunakan pada penelitian ini adalah kayu karet, biji kakao, borang yang berupa rincian biaya pembuatan alat, dan rincian biaya yang dikeluarkan selama pengujian.

\section{Pengumpulan Data}

Data-data yang diperlukan dalam melakukan analisis ekonomi ini diperoleh dari data kuantitatif yang didukung oleh data kualitatif, hal ini dilakukan untuk mendapatkan hasil yang akurat. Data 
kualitatif diperoleh dari mewawancarai secara langsung petani pemilik mesin menggunakan daftar pertanyaan (kuesioner) sebagai alat bantu pengumpulan data. Pemilik, operator, teknisi dan petani pengguna alat pengering biji kakao di desa tempat pelaksanaan penelitian menjadi responden dalam proses penelitian ini. Sedangkan data kuantitatif diperoleh dengan melakukan pengamatan atau pengukuran langsung di lapangan. Untuk dapat menganalisis kebutuhan biaya dalam proses pengeringan biji kakao maka dilakukan pengamatan langsung di lapangan berupa kapasitas kerja dari alat pengering biji kakao tipe bak sistem penghembus udara panas.

Data-data yang diperlukan diisi kedalam tabel yang sesuai dengan data dan rincian biaya yang telah dikeluarkan. Data-data yang diperlukan adalah rincian data analisis ekonomi alat pengering biji kakao tipe bak sistem penghembus udara panas meliputi biaya pembuatan alat, suku bunga bank, umur ekonomis alat, biaya sewa bangunan, biaya bahan baku, jumlah operator, upah operator, kapasitas alat, jam kerja alat, hari kerja alat, biaya pemeliharaan dan perbaikan, daya kipas, biaya listrik, konsumsi bahan bakar, biaya bahan bakar, dan biaya jasa pengeringan.

Sedangkan biaya operasional kendaraan pada meliputi biaya pembelian mobil, biaya pajak kendaraan, biaya uji KIR, jumlah operator, upah operator, jam operasional kendaraan, hari operasional kendaraan, biaya pemeliharaan dan perbaikan, biaya bahan bakar, jarak tempuh, BBM pertalite, biaya oli dan filter, dan biaya ban.

\section{Analisis Data}

Data-data yang diperoleh digunakan untuk menentukan, diantaranya; biaya tetap, biaya tidak tetap, biaya total, biaya pokok pengeringan, laba, analisis titik impas, Net Present Value, B/C Ratio, dan IRR. Hargaharga yang digunakan adalah harga yang berlaku pada saat pengujian dan pengolahan data.

\section{Analisis Biaya}

Biaya Tetap (Fixed Cost) (Giatman, 2006)

Biaya Penyusutan (D) per Tahun (Kibria, 1995)

$\mathrm{S}=10 \% \times \mathrm{P}$

$\mathrm{D} \quad=(\mathrm{P}-\mathrm{S}) / \mathrm{n}$

Keterangan:

$\mathrm{S}=$ Nilai sisa alat, $\mathrm{Rp}$

$\mathrm{D}$ = Biaya penyusutan, Rp/tahun

$\mathrm{P} \quad=$ Harga alat, $\mathrm{Rp}$

$\mathrm{n}=$ Umur ekonomis alat, 5 tahun

Biaya Gudang (BG) per Tahun

$\mathrm{BG}=$ Harga sewa bangunan/bl $\times 12 \mathrm{bl}$.....(3)

Biaya Pajak Kendaraan

Biaya $=$ Harga pajak kendaraan $\times 1 /$ th.....(4)

Biaya Uji KIR

Biaya $=$ Harga Uji KIR $\times 2 /$ th.

Biaya Tidak Tetap (Variable Cost)

(Giatman, 2006)

Biaya Bahan Baku

Biaya $=$ Jml beli produk $\times$ Harga beli .....(6)

Biaya Operator (BO) (Agustina dkk, 2013)

$\mathrm{BO}=\mathrm{Op} \times \mathrm{Uop} \times \mathrm{HK} \times \mathrm{JK}$.

Keterangan:

$\mathrm{BO}=$ Biaya operator, $\mathrm{Rp}$

Op = Jumlah operator, 2 orang

Uop = Upah operator, $\mathrm{Rp}$

$\mathrm{JK}=\mathrm{Jam}$ kerja alat, jam/hari

Biaya Pemeliharaan dan Perbaikan (BPP) (Kibria, 1995)

$\mathrm{BPP}=\mathrm{P} \times \frac{\mathrm{m}}{100}$

Keterangan:

$\mathrm{P} \quad=$ Harga alat, $\mathrm{Rp}$

$\mathrm{m}=$ Nilai pemeliharaan dan perbaikan, 5\%/tahun (Kibria, 1995)

Biaya Pemakaian Listrik (BL) (Mukhlis, 2012)

$\mathrm{BL}=\mathrm{W} \times \mathrm{HL} \times \mathrm{JK} \times \mathrm{HK}$

Keterangan:

$\mathrm{BL}=$ Biaya listrik, $\mathrm{Rp} /$ tahun 
$\mathrm{W}=$ Daya, 80 Watt $(0,08 \mathrm{~kW})$ (Spesifikasi Alat)

$\mathrm{HL}=$ Harga listrik, Rp 1.467,28/kWh (PLN Persero, 2018)

$\mathrm{JK}=$ Jam kerja alat, jam/hari

$\mathrm{HK}=$ Hari kerja alat, hari/tahun

Biaya Bahan Bakar (BBB) Alat (Agustina dkk, 2013)

$\mathrm{BBB}=\mathrm{KBB} \times \mathrm{HBB} \times \mathrm{HK} \times \mathrm{JK}$

Keterangan:

$\mathrm{KBB}=$ Konsumsi bahan bakar, $\mathrm{Rp} / \mathrm{kg}$

$\mathrm{HK}=$ Hari kerja alat, hari/tahun

HBB = Harga bahan bakar, Rp

$\mathrm{JK}=$ Jam kerja alat, jam/hari

Biaya Bahan Bakar Mobil (Oetojo, 2014)

$\mathrm{BBBM}=\mathrm{KBBM} \times \mathrm{HBBM} \times \mathrm{JK} \times \mathrm{HK} . .(11)$

Keterangan:

$\mathrm{BBBM}=$ Biaya bahan bakar minya kendaraan, Rp/tahun

$\mathrm{KBBM}=$ Konsumsi bahan bakar minyak kendaraan, liter $/ \mathrm{km}$

HBBM = Harga bahan bakar minyak kendaraan, $\mathrm{Rp}$

$\mathrm{JK}=$ Jam kerja alat, jam/hari

HK = Hari kerja alat, hari/tahun

Biaya Oli dan Filter

Biaya $=$ Harga oli dan filter $\times 2 /$ tahun...(12)

Biaya Ban

Biaya $=$ Harga ban $\times 4 \times 1 /$ tahun

Biaya Total (Total Cost) per Tahun (Septiaji, dkk., 2017)

$\mathrm{TC}=\mathrm{FC}+\mathrm{VC}$.

Keterangan:

$\mathrm{TC}=$ Biaya total, $\mathrm{Rp} /$ tahun

$\mathrm{FC}=$ Biaya tetap, $\mathrm{Rp} /$ tahun

$\mathrm{VC}=$ Biaya tidak tetap, $\mathrm{Rp} /$ tahun

Biaya Pokok Pengeringan (BP) per Tahun (Mulyadi, 2008 dalam Gunawan dkk, 2016)

$\mathrm{BP}=\frac{\mathrm{TC}}{\text { kakao kering yang dihasilkan }}$

Keterangan:

$\mathrm{BP}=$ Biaya pokok pengeringan, $\mathrm{Rp} / \mathrm{kg}$
$\mathrm{TC}=$ Biaya total, Rp/tahun

Omset per Tahun (Saragih, 2017)

Omset $=$ Jumlah jual produk $\times$ Harga jual

produk

Laba $(\pi)$ per Tahun (Sari, 2011)

$\pi=$ Omset - TC.

Keterangan:

$\pi \quad=$ Total laba, Rp/tahun

$\mathrm{TC}=$ Biaya total, Rp/tahun

Analisis Titik Impas (Break Even Point) (Agustina dkk, 2013)

$\begin{aligned} \mathrm{VC}_{\text {unit }} & =\frac{\mathrm{VC}}{\mathrm{k} \times \mathrm{HK}} \ldots \ldots \ldots \ldots . . . \\ \mathrm{BEP} & =\frac{\mathrm{FC} \text { harga pembelian }}{\text { Harga jual }- \text { VCunit }} .\end{aligned}$

Keterangan:

$\mathrm{VC}_{\text {unit }}=$ Biaya tidak tetap per unit, $\mathrm{Rp} / \mathrm{kg}$

$\mathrm{VC}=$ Biaya tidak tetap, $\mathrm{Rp} /$ tahun

$\mathrm{k}=$ Kapasitas kerja alat, $\mathrm{kg} / \mathrm{hari}$

$\mathrm{HK}=$ Hari kerja alat, hari/tahun

$\mathrm{FC}=$ Biaya tetap dari harga pembelian, $\mathrm{Rp}$

Analisis Kelayakan (Pasaribu, 2012)

Discount factor (DF) atau faktor potongan

DF $=\frac{1}{(1+\mathrm{i})^{\mathrm{t}}}$

Keterangan:

$\mathrm{i}=$ Discount rate/suku bunga bank, 7\% (Bank Mandiri, 2018)

$\mathrm{t} \quad=$ Tahun ke- $\mathrm{t}$

Net Present Value (NPV) (Pasaribu, 2012) NPV dapat dihitung dengan persamaan 21 .

$\mathrm{NPV}=\Sigma \frac{\mathrm{B}_{\mathrm{t}}-\mathrm{C}_{\mathrm{t}}}{(1+\mathrm{i})^{\mathrm{t}}}$

Keterangan:

$\mathrm{B}_{\mathrm{t}} \quad=$ Nilai total penerimaan sekarang

$\mathrm{C}_{\mathrm{t}} \quad=$ Nilai total pengeluaran sekarang

$\mathrm{i} \quad=$ Discount rate/suku bunga bank

$\mathrm{t} \quad=$ Tahun ke- $\mathrm{t}$ 
Benefit Cost Ratio (B/C Ratio) (Pasaribu, 2012)

Untuk mendapatkan hasil perbandingan antara Benefit terhadap Cost digunakan rumus 22 .

$\mathrm{B} / \mathrm{C}$ Ratio $=\frac{\Sigma \frac{\mathrm{B}_{\mathrm{t}}}{(1+\mathrm{i})^{\mathrm{t}}}}{\Sigma \frac{\mathrm{C}_{\mathrm{t}}}{(1+\mathrm{i})^{\mathrm{t}}}}$

Keterangan:

$\mathrm{B}_{\mathrm{t}} \quad=$ Nilai total penerimaan sekarang

$\mathrm{C}_{\mathrm{t}} \quad=$ Nilai total pengeluaran sekarang

$\mathrm{i} \quad=$ Discount rate/suku bunga bank

$\mathrm{t} \quad=$ Tahun ke- $\mathrm{t}$

Internal Rate of Return (IRR) (Pasaribu, 2012)

Nilai IRR dapat dihitung dengan persamaan 23 berikut.

IRR $=i^{\prime}+\frac{N P V^{\prime}}{N P V^{\prime}-N P V^{\prime \prime}}\left(i^{\prime \prime}-i^{\prime}\right)$

Keterangan:

i' = discount rate yang menghasilkan NPV positif

i” = discount rate yang menghasilkan NPV negatif
NPV' = NPV positif

NPV” = NPV negative

\section{Analisis Sensitivitas}

Menurut Pasaribu (2012), analisis sensitivitas dilakukan dengan 3 cara, yakni: (i) biaya produksi naik sebesar $10 \%$, sementara penerimaan tetap, (ii) penerimaan turun $10 \%$; sementara biaya produksi tetap, dan (iii) jam kerja alat menjadi 14 jam (Lampiran 2). Prosedur perhitungan yang dilakukan sama terhadap ketiga cara tersebut, termasuk menentukan nilai NPV, $\mathrm{B} / \mathrm{C}$ ratio, dan IRR menggunakan tabel discount factor.

\section{HASIL DAN PEMBAHASAN}

\section{Hasil Penelitian}

Data biaya yang dikeluarkan dalam pembuatan alat pengering biji kakao tipe bak sistem penghembus udara panas dapat dilihat pada tabel 1 .

Tabel 1. Biaya yang dikeluarkan dalam pembuatan alat pengering biji kakao

\begin{tabular}{|c|c|c|c|c|}
\hline No. & Uraian & Volume & Harga Satuan & Jumlah \\
\hline \multirow[t]{8}{*}{1} & Alat & & & \\
\hline & Kipas & 1 buah & $\begin{array}{ll}\mathrm{Rp} & 550.000,00\end{array}$ & $550.000,00$ \\
\hline & Drum besi plat & 6 drum & $\mathrm{Rp} \quad 100.000,00$ & $600.000,00$ \\
\hline & Kaki plat & 6 batang & Rp $\quad 150.000,00$ & $900.000,00$ \\
\hline & Las & 1 buah & Rp $1.000 .000,00$ & $\mathrm{Rp} \quad 1.000 .000,00$ \\
\hline & Sekop & 4 buah & $70.000,00$ & $280.000,00$ \\
\hline & Artco & 2 buah & $\mathrm{Rp} \quad 350.000,00$ & $700.000,00$ \\
\hline & & & Jumlah & Rp $6.530 .000,00$ \\
\hline \multirow[t]{6}{*}{2} & Bahan & & & \\
\hline & Pasir & $\mathrm{m} 3$ & $\begin{array}{ll}\mathrm{Rp} & 200.000,00\end{array}$ & $600.000,00$ \\
\hline & Semen & 5 sak & $45.000,00$ & $225.000,00$ \\
\hline & Batako & 280 blok & $2.000,00$ & $560.000,00$ \\
\hline & Kawat las & $2 \mathrm{~kg}$ & $25.000,00$ & $50.000,00$ \\
\hline & & & Jumlah & Rp $1.435 .000,00$ \\
\hline \multirow[t]{5}{*}{3} & Lain-lain & & & \\
\hline & Tenaga kerja & orang & $\begin{array}{ll}\mathrm{Rp} & 300.000,00\end{array}$ & $600.000,00$ \\
\hline & & & Jumlah & $600.000,00$ \\
\hline & Total Biaya & & & Rp $6.065 .000,00$ \\
\hline & Harga Alat & $\mathrm{P}$ & (+30\% total biaya) & $\operatorname{Rp} 7.884 .500,00$ \\
\hline
\end{tabular}

Sumber: Hasil Pengolahan Data 
Tabel 2. Kapasitas kerja alat tiap ulangan (Akbar, 2018)

\begin{tabular}{llll}
\hline & Ulangan & & Rata-rata \\
\hline $\mathbf{1}$ & $\mathbf{2}$ & $\mathbf{3}$ & \\
\hline $607 \mathrm{~kg}$ & $600 \mathrm{~kg}$ & $594 \mathrm{~kg}$ & $600,33 \mathrm{~kg}$ \\
\hline
\end{tabular}

Tabel 3. Jam kerja alat tiap ulangan (Akbar, 2018)

\begin{tabular}{llll}
\hline & Ulangan & & Rata-rata \\
\hline $\mathbf{1}$ & $\mathbf{2}$ & $\mathbf{3}$ & \\
\hline $10 \mathrm{jam}$ & $11 \mathrm{jam}$ & $10 \mathrm{jam}$ & $10,33 \mathrm{jam}$ \\
\hline
\end{tabular}

Tabel 4. Konsumsi bahan bakar tiap ulangan (Akbar, 2018)

\begin{tabular}{llll}
\hline & Ulangan & & Rata-rata \\
\hline $\mathbf{1}$ & $\mathbf{2}$ & $\mathbf{3}$ & \\
\hline $101 \mathrm{~kg}$ & $123 \mathrm{~kg}$ & $91 \mathrm{~kg}$ & $105 \mathrm{~kg}$ \\
\hline
\end{tabular}

Tabel 5. Kadar air basah kakao tiap ulangan (Akbar, 2018)

\begin{tabular}{llll}
\hline & Ulangan & & Rata-rata \\
\hline $\mathbf{1}$ & $\mathbf{2}$ & $\mathbf{3}$ & \\
\hline $36,62 \%$ & $44,20 \%$ & $32,61 \%$ & $37,81 \%$ \\
\hline
\end{tabular}

Tabel 6. Kadar air kering kakao tiap ulangan (Akbar, 2018)

\begin{tabular}{llll}
\hline & Ulangan & & Rata-rata \\
\hline $\mathbf{1}$ & $\mathbf{2}$ & $\mathbf{3}$ & \\
\hline $8,50 \%$ & $8,72 \%$ & $7,80 \%$ & $8,34 \%$ \\
\hline
\end{tabular}

Tabel 7. Data Produksi Alat Pengering Biji Kakao Tipe Bak Sistem Penghembus Udara Panas

\begin{tabular}{|c|c|c|}
\hline No. & Keterangan & Jumlah \\
\hline 1 & Harga alat $(\mathrm{P}+30 \%)$ & $\mathrm{Rp} 7.884 .500,00$ \\
\hline 2 & Suku bunga KUR (i) & $7 \%$ \\
\hline 3 & Umur ekonomis alat (n) & 5 tahun \\
\hline 4 & Harga sewa bangunan & Rp 262.500,00/bulan \\
\hline 5 & Harga beli produk & $\mathrm{Rp} 13.000,00 / \mathrm{kg}$ \\
\hline 6 & Harga jual produk & $\mathrm{Rp} 25.000,00 / \mathrm{kg}$ \\
\hline 7 & Jumlah operator (Op) & 2 orang \\
\hline 8 & Upah operator (U Op) & Rp 100.000,00/hari \\
\hline 9 & Kapasitas kerja alat (k) & $600,33 \mathrm{~kg}$ \\
\hline 10 & Jam kerja alat (JK) & $10,33 \mathrm{jam} / \mathrm{hari}$ \\
\hline 11 & Hari kerja alat (HK) & 60 hari/tahun \\
\hline 12 & Pemeliharaan dan perbaikan (m) & $5 \% \mathrm{P} /$ tahun \\
\hline 13 & Tenaga kipas (W) & 80 watt \\
\hline 14 & Harga listrik (HL) & Rp $1.467,28 / \mathrm{kWh}$ \\
\hline 15 & Konsumsi bahan bakar (KBB) & $105 \mathrm{~kg} / \mathrm{hari}$ \\
\hline 16 & Harga bahan bakar (HBB) & $\mathrm{Rp} 75.000,00 / 500 \mathrm{~kg}$ \\
\hline 17 & Kadar air basah & $37,81 \%$ \\
\hline 18 & Kadar air kering & $8,34 \%$ \\
\hline
\end{tabular}

Sumber: Hasil Pengolahan Data 


\section{Biaya Tetap (Fixed Cost) Produksi}

Perhitungan biaya tetap pada alat pengering biji kakao tipe bak sistem penghembus udara panas meliputi biaya penyusutan dan biaya gudang. Besarnya biaya penyusutan pada pengujian menggunakan alat pengering biji kakao tipe bak sistem penghembus udara panas yaitu Rp 1.419.210,00/tahun dan biaya gudang yaitu Rp 3.150.000,00/tahun, serta telah ditambahkan dengan harga alat pengering yaitu sebesar Rp 7.884.500,00. Dengan demikian dapat diketahui besarnya nilai akhir alat pada pengujian. Analisis biaya tetap setelah dilakukan pengamatan dapat dilihat pada tabel 8 .

Tabel 8. Analisis biaya tetap produksi

\begin{tabular}{ll}
\hline Jenis Biaya & $\begin{array}{l}\text { Biaya Tetap } \\
\text { (Rp/tahun) }\end{array}$ \\
\hline Penyusutan & $1.419 .210,00$ \\
Gudang & $3.150 .000,00$ \\
Harga Alat & $7.884 .500,00$ \\
Jumlah & $12.453 .710,00$ \\
\hline
\end{tabular}

\section{Biaya Tetap (Fixed Cost) Operasional Kendaraan}

Perhitungan biaya tetap pada operasional kendaraan meliputi biaya penyusutan mobil transportasi, biaya pajak kendaraan dan biaya uji KIR.

Besarnya biaya penyusutan pada mobil transportasi yaitu sebesar Rp 9.000.000,00/tahun, biaya pajak kendaraan yaitu sebesar $\mathrm{Rp} 1.100 .000,00 /$ tahun, biaya uji KIR yaitu sebesar Rp 300.000,00/tahun serta telah ditambahkan dengan harga alat pengering yaitu sebesar Rp 50.000.000,00. Dengan demikian dapat diketahui besarnya nilai akhir alat pada pengujian. Analisis biaya tetap setelah dilakukan pengamatan dapat dilihat pada tabel 9.

Tabel 9. Analisis biaya tetap operasional kendaraan

\begin{tabular}{lll}
\hline Jenis Biaya & $\begin{array}{l}\text { Biaya } \\
\text { (Rp/tahun) }\end{array}$ & Tetap \\
\hline Penyusutan & $9.000 .000,00$ & \\
Pajak Kendaraan & $1.100 .000,00$ & \\
Uji KIR & $300.000,00$ & \\
Harga Mobil & $50.000 .000,00$ & \\
\hline
\end{tabular}

Jumlah $\quad 60.400 .000,00$

\section{Biaya Tidak Tetap (Variable Cost) Produksi}

Perhitungan biaya tidak tetap meliputi biaya operator, biaya pemeliharaan, biaya pemakaian listrik, dan biaya bahan bakar.

Biaya bahan baku adalah biaya yang dikeluarkan untuk setiap kali pembelian bahan baku kakao. Biaya bahan baku dihitung dengan cara mengetahui jumlah kakao kering yang dihasilkan terlebih dahulu kemudian dikalikan dengan harga pembelian kakao dari petani. Besarnya biaya pembelian bahan baku kakao yaitu sebesar Rp 468.260.000,00/tahun.

Biaya operator dikeluarkan untuk mengupah seseorang dalam mengoperasikan alat pengering biji kakao tipe bak sistem penghembus udara panas mulai dari memasukkan biji kakao hingga kering sesuai dengan kadar air yang ditentukan. Dasar penentuan biaya operator adalah besarnya upah buruh per hari di daerah dilaksanakannya penelitian. Besarnya upah buruh untuk 2 orang pekerja pada saat pengujian alat adalah sebesar $\mathrm{Rp}$ 12.000.000,00/tahun.

Biaya pemeliharaan dikeluarkan untuk menjaga dan memperbaiki alat agar alat tersebut dapat berfungsi dengan baik. Besarnya biaya pemeliharaan untuk alat ini beserta alat penggeraknya diperkirakan sebesar Rp 394.225,00/tahun.

Biaya pemakaian listrik adalah biaya yang dikeluarkan untuk menggerakkan motor kipas. Biaya listrik dihitung dengan cara mengetahui daya kipas terlebih dahulu kemudian dikalikan dengan harga listrik PLN yang berlaku pada saat pengujian. Besarnya biaya listrik alat ini diperkirakan sebesar Rp 72.777,09/tahun.

Biaya bahan bakar dihitung dengan cara menghitung jumlah bahan bakar yang terpakai selama per satu ulangan dikalikan dengan harga bahan bakar yang berlaku pada saat pengujian. Besarnya konsumsi bahan bakar pada masing-masing ulangan berbeda-beda, maka jumlah bahan bakar yang digunakan adalah pembulatan dari 
rata-rata bahan bakar yang digunakan pada masing-masing ulangan. Besarnya biaya bahan bakar alat ini diperkirakan sebesar Rp 945.000,00/tahun.

Tabel 10. Analisis biaya tidak tetap produksi

\begin{tabular}{lll}
\hline Jenis Biaya & $\begin{array}{l}\text { Biaya Tidak } \\
\text { (Rp/tahun) }\end{array}$ & Tetap \\
\hline Bahan Baku & $468.260 .000,00$ & \\
Operator & $12.000 .000,00$ & \\
Pemeliharaan dan & $394.225,00$ \\
Perbaikan & $72.777,09$ \\
Listrik & $945.000,00$ \\
Bahan Bakar Alat & $481.672 .002,09$ \\
Jumlah
\end{tabular}

\section{Biaya Tidak Tetap (Variable Cost)} Operasional Kendaraan

Perhitungan biaya tidak tetap meliputi biaya operator, biaya pemeliharaan, biaya bahan bakar, biaya oli dan filter, serta biaya ban.

Biaya operator dikeluarkan untuk mengupah seseorang dalam mengoperasikan kendaraan mulai dari lokasi pengeringan sampai dengan ke pabrik. Dasar penentuan biaya operator adalah besarnya upah buruh per hari di daerah dilaksanakannya penelitian. Besarnya upah buruh untuk 2 orang pekerja pada saat pengujian alat adalah sebesar Rp 6.000.000,00/tahun.

Biaya pemeliharaan dikeluarkan untuk menjaga dan memperbaiki kendaraan agar kendaraan tersebut dapat berfungsi dengan baik. Besarnya biaya pemeliharaan untuk alat ini beserta alat penggeraknya diperkirakan sebesar Rp2.500.000,00 /tahun.

Biaya bahan bakar mobil dihitung dengan cara menghitung jumlah bahan bakar yang terpakai per satu rit pulang pergi dari lokasi pengeringan ke pabrik, kemudian dikalikan dengan harga bahan bakar minyak yang berlaku pada saat pengujian. Besarnya konsumsi bahan bakar mobil yaitu sebesar 1:10 atau 1 liter/10 km. Besarnya biaya bahan bakar alat ini yaitu sebesar $\mathrm{Rp}$ 2.808.000,00/tahun.

Biaya oli dan filter adalah biaya yang dikeluarkan untuk setiap kali penggantian oli dan filter kendaraan. Biaya oli dan filter dihitung dengan cara mengetahui harga oli dan filter terlebih terlebih dahulu kemudian dikalikan dengan jumlah penggantiannya selama satu tahun. Besarnya biaya oli dan filter kendaraan ini yaitu sebesar $\mathrm{Rp}$ 900.000,00/tahun.

Biaya ban adalah biaya yang dikeluarkan untuk setiap kali penggantian ban kendaraan. Biaya ban dihitung dengan cara mengetahui harga ban terlebih terlebih dahulu kemudian dikalikan dengan jumlah ban mobil, yaitu 4 . Kemudian dikalikan dengan jumlah penggantiannya selama satu tahun. Besarnya ban kendaraan ini yaitu sebesar Rp 2.000.000,00/tahun.

Tabel 11. Analisis biaya tidak tetap operasional kendaraan

\begin{tabular}{lll}
\hline Jenis Biaya & $\begin{array}{l}\text { Biaya Tidak } \\
\text { (Rp/tahun) }\end{array}$ & Tetap \\
\hline Operator & $6.000 .000,00$ & \\
Pemeliharaan dan & $2.500 .000,00$ \\
Perbaikan & $2.808 .000,00$ \\
Bahan Bakar Mobil & $900.000,00$ \\
Oli dan Filter & $2.000 .000,0$ \\
Ban & $14.208 .000,00$ \\
Jumlah & \\
\hline
\end{tabular}

\section{Biaya Total (Total Cost)}

Biaya total adalah penjumlahan biaya tetap dan biaya tidak tetap dari biaya produksi dan biaya operasional kendaraan. Analisis biaya total setelah pengujian, dilakukan perhitungan disajikan pada Tabel 12.

Tabel 12. Analisis biaya total alat pengering biji kakao tipe bak sistem penghembus udara panas

\begin{tabular}{ll}
\hline Keterangan & $\begin{array}{l}\text { Jumlah } \\
\text { (Rp/tahun) }\end{array}$ \\
\hline Biaya Tetap Produksi & $12.453 .710,00$ \\
$\begin{array}{l}\text { Biaya Tidak Tetap } \\
\text { Produksi }\end{array}$ & $481.672 .002,09$ \\
$\begin{array}{l}\text { Biaya Tetap Operasional } \\
\text { Kendaraan }\end{array}$ & $60.400 .000,00$ \\
$\begin{array}{l}\text { Biaya Tidak Tetap } \\
\text { Operasional Kendaraan }\end{array}$ & $14.208 .000,00$ \\
\hline Biaya Total & $568.733 .712,09$ \\
\hline
\end{tabular}




\section{Biaya Pokok Pengeringan}

Untuk menghitung biaya pokok alat pengering biji kakao tipe bak sistem penghembus udara panas, diperlukan data kakao kering yang dihasilkan. Adapun kakao kering yang dihasilkan dari alat pengering ini yaitu $23.271,51 \mathrm{~kg} /$ tahun.

Alat pengering biji kakao tipe bak sistem penghembus udara panas memliki kapasitas maksimal alat sebesar 1 ton (1.000 $\mathrm{kg}$ ) dengan penggunan pada saat penelitian kurang lebih 6 kwintal $(600,33 \mathrm{~kg})$, hal ini dikarenakan sulitnya pengumpulan sumber daya kakao dan rendahnya daya kipas yang hanya sebesar 80 watt serta pengoperasian alat selama 10,33 jam/hari.

Dalam 1 tahun terdapat 60 hari proses pengeringan biji kakao, yaitu 4 bulan masa pemanenan awal kakao, 4 bulan masa panen raya kakao, dan 4 bulan masa penutupan panen kakao. Pada masa pemanenan awal dan penutupan kakao, pengeringan hanya terlaksana sekitar 1 kali per minggu atau 4 kali per bulan, sedangkan pada masa penen raya, pengeringan dapat dilakukan 2 kali per minggu atau 8 kali per bulan. Fenomena tersebut terjadi dikarenakan kondisi lingkungan memiliki sumber daya kakao yang minim.

\section{Laba}

Laba merupakan selisih dari nilai omset penjualan (Benefit) dan nilai pengeluaran (Cost). Nilai pemasukan dihitung berdasarkan jumlah biji kakao basah yang dikeringkan dikalikan harga jual biji kakao kering Rp 25.000,00/kg. Analisis laba/keuntungan per tahun pada pengujian alat pengering disajikan pada tabel 13 .
Tabel 13. Analisis laba/keuntungan alat pengering biji kakao tipe bak sistem penghembus udara panas

\begin{tabular}{ll}
\hline Keterangan & Jumlah $($ Rp/tahun) \\
\hline Omset & $610.976 .380,10$ \\
Pengeluaran & $568.733 .712,09$ \\
Laba & $42.242 .668,01$ \\
\hline
\end{tabular}

\section{Analisis Titik Impas (Break Even Point)}

Titik impas yang terjadi pada alat pengering biji kakao tipe bak sistem penghembus udara panas tercapai pada kapasitas 5.152,98 $\mathrm{kg}$ atau 8,58 hari pengeringan. Hal ini menunjukkan bahwa alat pengering biji kakao tipe bak sistem penghembus udara panas mampu menekan biaya produksi sehingga laba yang diperoleh akan lebih tingg.

\section{Analisis Kelayakan}

Analisis kelayakan dilakukan untuk menentukan layak atau tidaknya suatu usaha dijalankan. Perhitungan analisis kelayakan pada alat pengering biji kakao tipe bak sistem penghembus udara panas dilakukan dengan menggunakan 3 jenis perhitungan yaitu Net Present Value (NPV), Benefit Cost Ratio (B/C Ratio), dan Internal Rate of Return (IRR). Penyusunan arus kas pada setiap tahun selama umur proyek baik untuk arus biaya maupun manfaat sehingga nilai sekarang (Present Value) dapat dihitung dengan menggunakan Disount Factor (DF).

Menghitung arus kas baik biaya pengeluaran maupun pemasukan dikonversikan ke dalam rupiah per tahun. Data biaya pengeluaran dan pemasukan dikalikan dengan perkiraan jam kerja alat selama 1 tahun yaitu $620 \mathrm{jam} /$ tahun $(10,33$ jam/hari $\times 60$ hari/tahun). Arus kas pada alat pengering biji kakao tipe bak sistem penghembus udara panas disajikan pada tabel 14.

Tabel 14. Arus kas pada pengeringan biji kakao

\begin{tabular}{llllll}
\hline Tahun & \multicolumn{1}{c}{$\begin{array}{c}\text { Cost } \\
(\mathrm{Rp})\end{array}$} & $\begin{array}{c}\text { Benefit } \\
(\mathrm{Rp})\end{array}$ & DF 7\% & $\begin{array}{c}\text { PVC } \\
(\mathrm{Rp})\end{array}$ & $\begin{array}{c}\text { PVB } \\
(\mathrm{Rp})\end{array}$ \\
\hline 0 & $7.884 .500,00$ & & 1 & $7.884 .500,00$ & \\
1 & $568.733 .712,09$ & $610.976 .380,10$ & 0,93 & $531.526 .833,73$ & $571.005 .962,71$
\end{tabular}




\begin{tabular}{llllll}
2 & $568.733 .712,09$ & $610.976 .380,10$ & 0,87 & $496.754 .050,21$ & $533.650 .432,44$ \\
3 & $568.733 .712,09$ & $610.976 .380,10$ & 0,82 & $464.256 .121,69$ & $498.738 .721,91$ \\
4 & $568.733 .712,09$ & $610.976 .380,10$ & 0,76 & $433.884 .225,88$ & $466.110 .955,05$ \\
5 & $568.733 .712,09$ & $610.976 .380,10$ & 0,71 & $405.499 .276,53$ & $435.617 .715,00$ \\
\hline
\end{tabular}

Analisis NPV, B/C Ratio, dan IRR pada alat pengering biji kakao tipe bak sistem penghembus udara panas disajikan pada tabel 15 .

Tabel 15. Analisis NPV, B/C Ratio, dan IRR pada alat pengering biji kakao tipe bak sistem penghembus udara panas

\begin{tabular}{ll}
\hline Keterangan & Jumlah \\
\hline NPV & Rp 165.318.779,07/tahun \\
B/C Ratio & 1,07 \\
IRR & $554,36 \%$ \\
\hline
\end{tabular}

Nilai Net Present Value (NPV) dihitung berdasarkan selisih jumlah nilai manfaat sekarang dengan jumlah nilai biaya sekarang selama umur ekonomis alat. Kriteria penilaian yakni apabila NPV bernilai positif. Dari hasil perhitungan, diperloleh nilai NPV sebesar Rp 165.318.779,07/tahun sehingga usaha dinyatakan layak.

Nilai Benefit/Cost Ratio (B/C Ratio) dilakukan untuk mencari perbandingan antara nilai biaya sekarang dengan nilai manfaat sekarang. Dengan menggunakan kriteria ini akan lebih menggambarkan pengaruh dari adanya tambahan biaya terhadap tambahan manfaat yang diterima. Dari hasil perhitungan, nilai $\mathrm{B} / \mathrm{C}$ Ratio yang diperoleh adalah 1,07. Nilai ini lebih besar dari indikator kelayakan yaitu $>1$, sehingga usaha layak.

Nilai IRR dilakukan dengan 2 tingkat suku bunga, indikator penilaiannya berupa nilai IRR lebih besar dari bunga pinjaman maka usaha dinyatakan diterima. Dari hasil perhitungan diperoleh nilai IRR adalah sebesar 554,36\%. Nilai tersebut lebih besar dari tingkat suku bunga yaitu 7\%, sehingga usaha ini dinyatakan layak.

\section{Analisis Sensitivitas}

Analisis sensitivitas dilakukan dengan cara simulasi perhitungan apabila terjadi perubahan asumsi dasar. Analisis sensitivitas mesin pengering biji kakao disajikan pada Tabel 16.

\section{Parameter perubahan}

a) Kenaikan biaya tidak tetap $10 \% \quad: \operatorname{Rp} 505.741 .029,80 /$ tahun

b) Penurunan kapasitas alat $10 \%: 540,30 \mathrm{~kg} / \mathrm{hari}$

c) Penurunan Jam kerja alat : : 14 jam

Tabel 16. Analisis sensitivitas mesin pengering kakao tipe bak penghembus udara panas

\begin{tabular}{lllll}
\hline Komponen & \multicolumn{3}{l}{ Kriteria investasi } & \\
\cline { 2 - 5 } & $\mathrm{NPV}$ (Rp/tahun) & $\mathrm{B} / \mathrm{C}$ ratio & $\mathrm{IRR}(\%)$ \\
\hline $\begin{array}{l}\text { Biaya produksi naik 10\%, } \\
\text { penerimaan tetap }\end{array}$ & $124.886 .618,54$ & 1,05 & 434,86 \\
\hline $\begin{array}{l}\text { Penerimaan turun 10\%, biaya } \\
\text { produksi tetap }\end{array}$ & $106.802 .245,50$ & 1,05 & 382,62 \\
\hline $\begin{array}{l}\text { Penurunan jam kerja alat } \\
\text { menjadi 14 jam }\end{array}$ & $165.212 .895,05$ & 1,07 & 554,05 \\
\hline
\end{tabular}

Berdasarkan perhitungan dan Tabel 16 , hasilnya menunjukkan bahwa perubahan biaya produksi, perubahan penerimaan, dan perubahan jam kerja alat memberikan pengaruh terhadap tingkat kelayakan finansial pengeringan biji kakao. 
Hasil analisis sensitivitas menunjukkan bahwa kenaikan biaya produksi pengeringan biji kakao sebesar $10 \%$ dapat menurunkan nilai NPV sebanyak $24,46 \%$ dari Rp 165.318.779,07/tahun menjadi $\quad \mathrm{Rp} \quad 124.886 .618,54 /$ tahun, penurunan nilai $\mathrm{B} / \mathrm{C}$ ratio sebanyak $1,87 \%$ dari 1,07 menjadi 1,05, dan penurunan nilai IRR sebanyak $21,56 \%$ dari $554,36 \%$ menjadi 434,86\%.

Penurunan penerimaan sebesar $10 \%$ dapat menurunkan nilai NPV sebanyak $35,40 \%$ dari $\mathrm{Rp}$ 165.318.779,07/tahun menjadi Rp 106.802.245,50/tahun, penurunan nilai $\mathrm{B} / \mathrm{C}$ ratio sebanyak $1,87 \%$ dari 1,07 menjadi 1,05, dan penurunan nilai IRR sebanyak 30,98\% dari 554,36\% menjadi $382,62 \%$.

Penurunan jam kerja alat menjadi 14 jam dapat menurunkan nilai NPV sebanyak 0,06\% dari Rp 165.318.779,07/tahun menjadi Rp 165.212.895,05/tahun, B/C ratio bernilai tetap yaitu 1,07 , dan penurunan nilai IRR sebanyak $0,06 \%$ dari $554,36 \%$ menjadi $554,05 \%$. Sehingga dari analisis sensitivitas alat pengeringan biji kakao tipe bak sistem penghembus udara panas dinyatakan tetap layak untuk dilakukan karena NPV bernilai positif, nilai $\mathrm{B} / \mathrm{C}$ ratio lebih dari 1, dan IRR memiliki nilai lebih tinggi daripada suku bunga bank.

\section{KESIMPULAN DAN SARAN}

\section{Kesimpulan}

Kesimpulan dari penelitian ini adalah sebagai berikut:

1. Laba per tahun yang diperoleh dari alat pengering biji kakao tipe bak sistem penghembus udara panas yaitu sebesar Rp 42.242.668,01/tahun.

2. Nilai Net Present Value (NPV) alat pengering biji kakao tipe bak sistem penghembus udara panas yaitu sebesar Rp 165.318.779,07/tahun.

3. Nilai Benefit/Cost Ratio (B/C Ratio) alat pengering biji kakao tipe bak sistem penghembus udara panas yaitu sebesar 1,07 .
4. Nilai Internal Rate of Return (IRR) alat pengering biji kakao tipe bak sistem penghembus udara panas yaitu sebesar $554,36 \%$.

\section{Saran}

Saran dari penelitian ini adalah sebagai berikut:

1. Perlu dilakukan peningkatan daya kipas (blower) yang akan digunakan sehingga ruang pengering dapat terpenuhi dan mampu memaksimalkan kinerja alat.

2. Perlu dilakukan analisis biaya lebih lanjut dengan menggunakan beberapa jenis bahan baku biji lain yang akan dikeringkan, dan bahan bakar kayu yang berbeda.

\section{DAFTAR REFERENSI}

Akbar, S.A. (2018). Uji Kinerja Alat Pengering Tipe Batch Dryer untuk Pengeringan Kakao (Theobroma Cacao L.) dengan Sistem Penghembus Udara Panas. (Skripsi). Universitas Lampung. Bandar Lampung. $82 \mathrm{hlm}$.

Agustina, R., Sutiarso, L., dan Karyadi, J.N.H. (2013). Sistem Pendukung Keputusan Teknologi Penanganan dan Kelayakan Investasi Pascapanen Kakao (Theobroma cacao L.) (Studi Kasus di Kabupaten Pidie Jaya, Propinsi Aceh). Agritech. 33(1):101111.

Bank Mandiri. (2018). Kredit Usaha Rakyat.

https://www.bankmandiri.co.id/kreditusaha-rakyat-kur.html. Diakses pada 20 Desember 2018.

BPS Provinsi Lampung. (2015). Lampung dalam Angka. Bandar Lampung.

Departemen Perindustrian. (2007). Gambaran Sekilas Industri Kakao. Sekretariat Jendral. Jakarta Selatan.

Giatman, M. (2006). Ekonomi Teknik. PT Raja Grafindo Persada. Jakarta. 212 hlm.

Harsanti, A., Juanda, B., dan Sahara. (2012). Dampak Bea Keluar Kakao Indonesia Terhadap Country Market 
Power di Pasar Biji Kakao Amerika Serikat dan Terms of Trade. Jurnal Agribisnis Indonesia. 2(2):107-126.

Mukhlis, B. (2012). Biaya Pemasangan Baru dan Perhitungan Rekening Listrik Rumah Tangga. Jurnal Ilmiah Foristek. 2(1):165-170.

Napitupulu, F.H., dan Tua, P.M. (2012). Perancangan dan Pengujian Alat Pengering Kakao dengan Tipe Cabinet Dryer untuk Kapasitas 7,5 kg PerSiklus. Jurnal Dinamis. 2(10):8-18.

Pasaribu, A.M. (2012). Perencanaan \& Evaluasi Proyek Agribisnis (Konsep \& Aplikasi). Lily Publisher. Yogyakarta. $182 \mathrm{hlm}$.

PLN Persero. (2018). Tarif Dasar Listrik. https://www.pln.co.id/blog/siaran- pers/2017/12/pln-pastikan-tarif-listriktidak-naik.html. Diakses pada 1 Juli 2018.

Sadimantara, M.S., Tamrin, dan Asyik, N. (2014). Analisis Kelayakan Produksi Bubuk Kakao Sistem Vacuum Roasting dan Lemak Kakao Skala Industri Kecil. Agriplus, 24 (3): 258264.

Septiaji, I.D., Cepriyadi, dan Tety, E. (2017). Analisis Nilai Tambah Agroindustri Produk Hilir Kakao (Studi Kasus Pabrik Mini Chocato Kelurahan Kapalo Koto, Kecamatan Payakumbuh Selatan, Sumatera Barat). Jurnal Agribisnis, 19 (2): 115. 